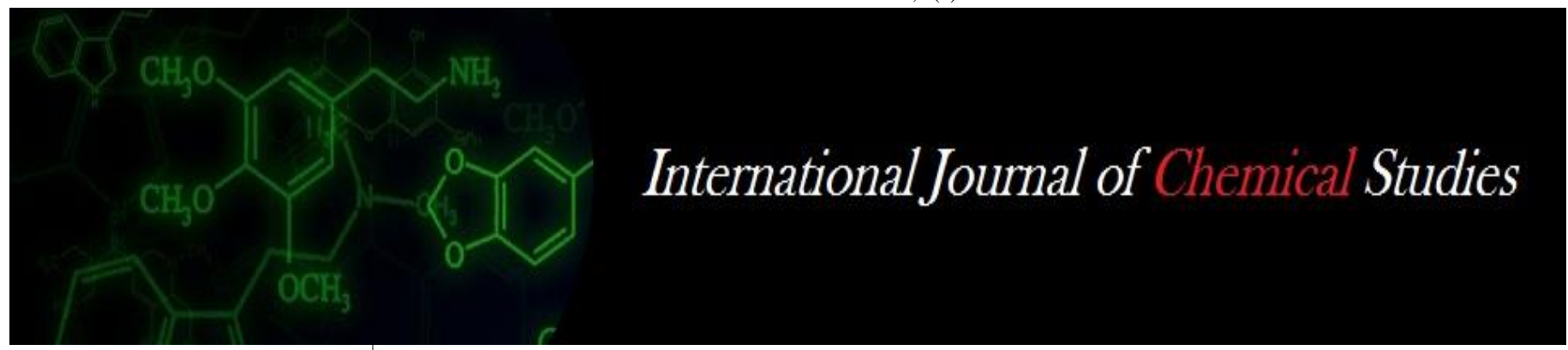

P-ISSN: 2349-8528

E-ISSN: 2321-4902

www.chemijournal.com

IJCS 2020; 8(2): 1312-1314

(C) 2020 IJCS

Received: 19-01-2020

Accepted: 23-02-2020

Potala Harshita Mala

Department of Sericulture,

College of Agriculture

University of Agricultural

Sciences, GKVK, Bengaluru,

Karnataka, India

S Chandrashekhar

Department of Sericulture,

College of Agriculture

University of Agricultural

Sciences, GKVK, Bengaluru,

Karnataka, India
Corresponding Author:

Potala Harshita Mala

Department of Sericulture,

College of Agriculture

University of Agricultural

Sciences, GKVK, Bengaluru,

Karnataka, India

\section{Physico-chemical properties of mulberry field soil as influenced by the application of Seri-waste bio- digester effluent}

\section{Potala Harshita Mala and S Chandrashekhar}

DOI: https://doi.org/10.22271/chemi.2020.v8.i2t.8947

\begin{abstract}
A field experiment was conducted to study the physico-chemical properties of mulberry field soil as influenced by the application of seri-waste biodigester liquid to $\mathrm{V}_{1}$ mulberry garden on clay loamy soil during 2017-18. Application of 50\% Seri Bio-digester effluent $+25 \%$ Biodigester effluent $+25 \%$ Recommended dose of fertilizers (RDF) recorded the highest major nutrient contents (available N, P2O5, $\mathrm{K} 2 \mathrm{O}$ of $285.38,49.82$ and $186.05 \mathrm{~kg} / \mathrm{ha}$ ) in soil compared to control. Application of $50 \%$ Seri Biodigester effluent $+25 \%$ Biodigester effluent $+25 \%$ RDF also significantly increased the physicochemical properties of mulberry field soil.
\end{abstract}

Keywords: Mulberry, seri waste biodigester, physico - chemical properties of soil.

\section{Introduction}

Biogas is used as a major source of household energy. The substratum which is high in moisture content such as seri-waste and animal manure are suitable for producing biogas using anaerobic digester technology. In the biogas generation process, the composted liquid slurry of around $80-90$ per cent solid waste is introduced into the digester. The temperature is maintained at 25 to 35.5 degrees celsius with pH of 6.7 to 9.4 and the contents of the digester are continuously stirred. Besides biogas, the biogas slurry, resulting as a product of anaerobic fermentation of animal excrements and other wastes in the biogas digester, is an excellent organic fertilizer which can make an important contribution to better crop yields and long lasting soil fertility.

The fermented slurry which contains relatively high percentage of readily available nutrients can be directly applied in liquid form to the crop plants both for basal and topdressing, in a dried form and also for compost preparation together with other organic materials.

Indiscriminate use of chemical fertilizers and pesticides leads to the increased soil fertility depletion. One of the ways to solve the problem is the promotion of integrated farming systems, with minimal external inputs and recycling of all wastes (Preston and Leng, 1989) ${ }^{[9]}$. The most important feature of this approach is the recycling of animal and plant wastes in order to prevent deterioration of soil fertility through loss of nutrients and organic matter, erosion and salinity (Rodriguez and Preston 1996) ${ }^{[7]}$.

Besides the nutrient supply, the biodigester effluent improves the physical and biological properties of soil. Bio slurry, in its different forms, is relatively free from foul smell, weedseeds and phytopathogenic organisms. It also improves soil porosity and water holding capacity. The slurry has bulk and fibre to hold soil manure. This may be called the anti-erosion quality of humus. In recent years, the biodigester liquid manure (a liquid material prepared using crop residues, animal waste, most importantly cow urine, dung etc. in a biodigester) has emerged as a promising organic liquid manure. Topdressing with biodigester liquid manure is known to increase the yields of finger millet, groundnut, sorghum, paddy and vegetable and horticultural crops to an extent of 10 to 70 per cent. 


\section{Materials and Methods}

Following were the treatments

1. $100 \%$ Recommended Dose of Fertilizers (RDF) (120:60:60 kg NPK ha/year)

2. $75 \%$ Seri Bio-digester effluent+ $25 \%$ RDF

3. $50 \%$ Seri Bio-digester effluent $+25 \%$ Compost $+25 \%$ $\mathrm{RDF}$

4. $50 \%$ Seri Bio-digester effluent $+25 \%$ Bio-digester effluent $+25 \% \mathrm{RDF}$

5. $25 \%$ Seri Bio-digester effluent+25\%Bio-digester effluent $+25 \%$ Vermicompost $+25 \%$ Compost

6. $75 \%$ Seri Bio-digester effluent $+25 \%$ Vermicompost

7. $50 \%$ Compost $+50 \%$ Seri bio-digester effluent

8. $100 \%$ Vermicompost

9. $100 \%$ Bio-digester effluent

10. $100 \%$ Compost

11. $100 \%$ Seri Bio-digester effluent

\section{Chemical properties of soil}

Soil samples were collected from different treatments at 60 days after pruning mulberry crop for the purpose of chemical analysis.

Soil $\mathrm{pH}$ was measured in 1:2.5 soil water-suspension, using $\mathrm{pH}$ meter. The clear supernatant of the above soil-water suspension was taken out and the Electrical conductivity (EC) was measured using conductivity bridge (Jackson, 1967) ${ }^{[3]}$. Soil organic carbon was estimated by wet oxidation method (Walkley and Black, 1934). Twenty grams of soil was distilled with $100 \mathrm{ml}$ of $0.1 \mathrm{~N} \mathrm{KMnO} 4$ and $100 \mathrm{ml}$ of 2.5 per cent $\mathrm{NaOH}$. The ammonia released during distillation was trapped in $4 \%$ boric acid containing mixed indicator and titrated against standard $\mathrm{H} 2 \mathrm{SO} 4$ and the available nitrogen was expressed in $\mathrm{kg} / \mathrm{ha}$ (Subbaiah and Asija, 1956) ${ }^{[9]}$. The available phosphorus in the soil was extracted with Olsen's reagent. The extracted phosphorus content was then estimated by chlorostannous reduced molybdophosphoric blue colour method. The intensity of blue colour was read in spectrophotometer (Jackson, 1967) ${ }^{[3]}$. The available soil potassium was extracted with neutral normal ammonium acetate solution and was estimated using flame photometer as described by Page et al. (1982). The micronutrient contents of $\mathrm{Zn}$ and $\mathrm{Fe}$ in the residues were determined by using atomic absorption spectrophotometer having appropriate hallow cathode lamps (Lindsey and Norwell, 1978).

\section{Results and Discussion \\ Influence of Seri waste biodigester on nutrient status of mulberry soil \\ Soil pH, EC and organic carbon}

Application of seriwaste biodigester liquid with recommended inorganic fertilizers and biodigester liquid influenced the soil $\mathrm{pH}$ and electrical conductivity of V1 mulberry plots (Table 1). The $\mathrm{pH}$ of the soil ranged from 7.81 in $50 \%$ Seri Bio-digester effluent $+25 \%$ Bio-digester effluent $+25 \%$ RDF to 8.21 in $100 \%$ recommended dose of fertilizers. The ideal soil $\mathrm{pH}$ for growth and development of mulberry plants was recorded in T4 (7.81) and T3 (50\% Seri Bio-digester effluent $+25 \%$ Compost $+25 \%$ RDF) of 7.91 . The soil $\mathrm{pH}$ was neutral in organic manures, which may be due to the degradation of hydrolysed polysaccharides during mineralisation and synthesis of organic acids by microorganisms through breakdown of the substrate which leads to maintenance of ideal pH (Jimenez and Garcia 1992) ${ }^{[4]}$. Helkaih et al. (1995) ${ }^{[2]}$ also reported that the improvement of EC might be due to the reduction of volume which inspite increases the concentration of nutrients and insoluble salts.

More organic carbon content $(0.71 \%)$ in soil was exhibited in $50 \%$ Seri Bio-digester effluent $+25 \%$ Bio-digester effluent + $25 \%$ RDF followed by $0.69 \%$ with $50 \%$ Seri Bio-digester effluent $+25 \%$ Compost $+25 \%$ RDF (Table 1). Lower soil organic carbon content $(0.59 \%)$ was exhibited in application of $100 \%$ recommended dose of fertilizers. The decomposition of organic manure is known to improve the organic matter content of soil thereby increasing the organic carbon (Garcia et al., 1993) ${ }^{[1]}$.

Table 1: Influence of seriwaste biodigester application on soil reaction, electrical conductivity and organic carbon of V1 mulberry garden soil on $60^{\text {th }}$ day after pruning

\begin{tabular}{|c|c|c|c|}
\hline Treatments & $\begin{array}{c}\text { Soil reaction } \\
(\mathbf{p H})\end{array}$ & Electrical conductivity $\left.\mathbf{d S m}^{-\mathbf{1}}\right)$ & $\begin{array}{c}\text { Organic carbon } \\
(\mathbf{\%})\end{array}$ \\
\hline $\mathrm{T}_{1}$ & 8.21 & 0.25 & 0.59 \\
\hline $\mathrm{T}_{2}$ & 7.96 & 0.28 & 0.64 \\
\hline $\mathrm{T}_{3}$ & 7.91 & 0.28 & 0.69 \\
\hline $\mathrm{T}_{4}$ & 7.81 & 0.30 & 0.71 \\
\hline $\mathrm{T}_{5}$ & 7.93 & 0.28 & 0.65 \\
\hline $\mathrm{T}_{6}$ & 7.96 & 0.27 & 0.63 \\
\hline $\mathrm{T}_{7}$ & 7.97 & 0.27 & 0.62 \\
\hline $\mathrm{T}_{8}$ & 8.21 & 0.25 & 0.60 \\
\hline $\mathrm{T}_{9}$ & 8.06 & 0.26 & 0.60 \\
\hline $\mathrm{T}_{10}$ & 8.10 & 0.26 & 0.60 \\
\hline $\mathrm{T}_{11}$ & 8.00 & 0.26 & 0.62 \\
\hline S.Em \pm & 0.031 & 0.008 & 0.006 \\
\hline C.D @ $(5 \%)$ & 0.092 & 0.023 & 0.018 \\
\hline
\end{tabular}

Table 2: Influence of seriwaste biodigester application on macronutrient status of V1 mulberry garden soil on $60^{\text {th }}$ day after pruning

\begin{tabular}{|c|c|c|c|}
\hline Treatments & Available N (kg/ha) & Available P $\mathbf{~ k g / h a ) ~}$ & Available K(kg/ha) \\
\hline $\mathrm{T}_{1}$ & 239.65 & 41.66 & 177.33 \\
\hline $\mathrm{T}_{2}$ & 275.97 & 48.51 & 185.40 \\
\hline $\mathrm{T}_{3}$ & 282.30 & 49.04 & 185.83 \\
\hline $\mathrm{T}_{4}$ & 285.38 & 49.82 & 186.05 \\
\hline $\mathrm{T}_{5}$ & 279.46 & 48.62 & 185.73 \\
\hline $\mathrm{T}_{6}$ & 273.88 & 48.37 & 184.49 \\
\hline $\mathrm{T}_{7}$ & 271.57 & 46.81 & 184.35 \\
\hline
\end{tabular}




\begin{tabular}{|c|c|c|c|}
\hline $\mathrm{T}_{8}$ & 244.28 & 42.04 & 180.07 \\
\hline $\mathrm{T}_{9}$ & 263.65 & 43.82 & 183.01 \\
\hline $\mathrm{T}_{10}$ & 244.28 & 43.35 & 182.05 \\
\hline $\mathrm{T}_{11}$ & 266.83 & 43.84 & 183.60 \\
\hline S.Em \pm & 1.020 & 0.381 & 0.638 \\
\hline C.D@ (5\%) & 3.010 & 1.125 & 1.882 \\
\hline
\end{tabular}

Table 3: Influence of seriwaste biodigester application on micronutrient status of V1 mulberry garden soil on $60^{\text {th }}$ day after pruning

\begin{tabular}{|c|c|c|c|c|}
\hline Treatments & $\mathbf{C u}(\mathbf{p p m})$ & $\mathbf{Z n}(\mathbf{p p m})$ & $\mathbf{F e}(\mathbf{p p m})$ & $\mathbf{M n}(\mathbf{p p m})$ \\
\hline $\mathrm{T}_{1}$ & 1.83 & 8.73 & 14.31 & 15.89 \\
\hline $\mathrm{T}_{2}$ & 3.86 & 12.59 & 18.89 & 23.32 \\
\hline $\mathrm{T}_{3}$ & 4.11 & 13.03 & 19.20 & 23.62 \\
\hline $\mathrm{T}_{4}$ & 4.31 & 13.17 & 19.33 & 24.35 \\
\hline $\mathrm{T}_{5}$ & 4.08 & 12.69 & 19.03 & 23.52 \\
\hline $\mathrm{T}_{6}$ & 3.85 & 12.50 & 18.77 & 22.62 \\
\hline $\mathrm{T}_{7}$ & 3.72 & 12.14 & 18.57 & 22.52 \\
\hline $\mathrm{T}_{8}$ & 2.66 & 9.82 & 15.49 & 20.21 \\
\hline $\mathrm{T}_{9}$ & 3.66 & 11.85 & 17.74 & 22.05 \\
\hline $\mathrm{T}_{10}$ & 3.66 & 10.56 & 17.39 & 20.88 \\
\hline $\mathrm{T}_{11}$ & 3.70 & 12.04 & 18.10 & 22.32 \\
\hline $\mathrm{S.Em} \pm$ & 0.094 & 0.510 & 0.460 & 0.641 \\
\hline C.D@ $(5 \%)$ & 0.276 & 1.505 & 1.357 & 1.892 \\
\hline
\end{tabular}

\section{Macro and Micro nutrients}

Significant soil fertility improvement was noticed with regard to macro and micro nutrient status of mulberry soil (Table 2). The availability of soil NPK in the mulberry garden increased due to the combined application of $50 \%$ Seri Bio-digester effluent $+25 \%$ Biodigester effluent $+25 \%$ RDF which recorded the highest available NPK content in soil $(285.38 \mathrm{~N}$, $49.82 \mathrm{P}$ and $186.05 \mathrm{~K} \mathrm{~kg} / \mathrm{ha})$ followed by T3 $(50 \%$ Seri Biodigester effluent $+25 \%$ Compost $+25 \%$ RDF) recording $282.30 \mathrm{~N}, 49.04 \mathrm{P}$ and $185.83 \mathrm{~K} \mathrm{~kg} / \mathrm{ha}$, respectively and the least $(239.65 \mathrm{~N}, 41.66 \mathrm{P}$ and $177.33 \mathrm{~K} \mathrm{~kg} / \mathrm{ha})$ was recorded in T1 $100 \%$ Recommended dose of fertilizers). The micronutrient availability in soil also increased due to the combined application of 50\% Seri Bio-digester effluent + $25 \%$ Bio-digester effluent $+25 \% \mathrm{RDF}$ registering the maximum availability of $\mathrm{Cu}, \mathrm{Zn}, \mathrm{Fe}$, and $\mathrm{Mn}$, (4.31ppm, $13.17 \mathrm{ppm}, 19.33 \mathrm{ppm}$ and $24.35 \mathrm{ppm}$ ) (Table 3). The next best treatment was $50 \%$ Seri Bio-digester effluent $+25 \%$ Compost $+25 \%$ RDF that recorded $4.11 \mathrm{ppm}, 13.03 \mathrm{ppm}$, $19.20 \mathrm{ppm}$ and $23.62 \mathrm{ppm}$ of $\mathrm{Cu}, \mathrm{Zn}, \mathrm{Fe}$, and $\mathrm{Mn}$, respectively and the least was found in $100 \%$ Recommended dose of fertilizers (1.83 ppm, $8.73 \mathrm{ppm}, 14.31 \mathrm{ppm}$ and15.89 ppm of $\mathrm{Cu}, \mathrm{Zn}, \mathrm{Fe}$, and $\mathrm{Mn}$, respectively). These results are comparable with the observations of Rashmi et al. (2006) ${ }^{[8]}$ as per whom the application of various sources of organic manures combined with chemical fertilizers significantly elevated the available macro and micro nutrients in the mulberry soil.

\section{References}

1. Garcia C, Hernandez T, Costa F, Cecanti C. Ganni A. Hydrolases in organic matter fraction of sewage sludge: changes in composting. Biores Technol. 1993; 44:17-23

2. Helkaih J, Parwin Banu KS, Rajanna G, Ramaswami PP. Studies on distillery effluent based compost and its utility. Report submitted to Tamil Nadu Agril. Univ., Coimbatore, 1995, 144.

3. JACKSON ML. Soil chemical analysis, Prentice Hall of India (Pvt.) Ltd., New Delhi, 1967, 498.

4. Jimenez EI, Garcia VP. Composting domestic refuse and sewage sludge, evolution of temperature, $\mathrm{pH}, \mathrm{C} / \mathrm{N}$ ratio and cation exchange capacity. Res. Conser. Recycle. $1992 ; 6: 45-60$.
5. Lindsey WL, Norwell WA. Development of DTPA soil test for zinc, iron, manganese and copper. Soil Sci. Soc. Am. J. 1978; 42:421-428.

6. Page AL, Miller RH, Kenay DR. Methods of Soil analysis part-2. Soil science of America. Inc. Pubis. Madison, Wisconsin, USA, 1982.

7. Preston TR, Leng RA. The greenhouse effect and its implications for world agriculture. The need for environmentally friendly development. Livestock Research for Rural Development. 1989; 1(1):21-30.

8. Rashmi K, Shankar MA, Narayanaswamy TK, Sreeramuliu KR, Rajegowda. Effect of application of organic manures and inorganic fertilizers on growth, yield and quality of S36 mulberry. Natl. Conf. New. Strat. Res. Dev. Seric.-Indian Perspective. $9^{\text {th }}-10^{\text {th }}$ March 2006, Bangalore University, Bangalore, 2006, 36-37.

9. Subbiah BY, Asija GL. A rapid procedure for the estimation of available nitrogen in soils. Curr. Sci. 1956; 25:259-260.

10. Rodriguez L, Preston TR. Recent developments in the recycling of livestock excreta; an essential feature of sustainable farming systems in the tropics, 1996.

11. Walkley AJ, Black IA. An examination of the method for determining soil organic matter and a proposed modification of the chromic acid titration method. J Soil Sci. 1934; 37:29-38. 